\title{
Communicating to the Ages: Influence of Age on Florida Residents' Informational Processing Behaviors'
}

\author{
Amanda D. Ali, Laura A. Sanagorski Warner, Ashley N. McCleod, Shelli Rampold, and Alexa J. \\ Lamm $^{2}$
}

\section{Introduction}

Florida is a peninsula state surrounded by water with many inland waterways. An important issue surrounding water quality is pollution from improper fertilizer application by Florida residents (Shaddox \& Unruh, 2017). Enhanced Extension programs can help to effectively educate Florida residents on proper fertilizer application and water quality concerns (Lamm, Warner, Martin, White, \& Fisher, 2017). The progression of communication trends provides opportunities for innovative ways to connect with audiences (Moore, Meyers, Irlbeck, \& Burris, 2015). Web-based videos are a possible tool Extension can use to educate various audiences about water conservation and proper fertilizer use (Lamm et al., 2017). Video messages about fertilizer best practices were created and tested for this study. To promote well-designed educational videos for Florida residents, it is important to understand how they process information received. This study applied the Elaboration Likelihood Model (ELM) to understand how video messages were processed by different audiences. This document explores how Florida residents processed video messages about fertilizer best practices and explored if their information-processing behaviors differed by age. The objectives of this study were to determine:
- how different age groups processed video messages about good fertilizer use

- the type of messages best suited for different age groups

This document concludes with recommendations for the use of video messages in Extension programs to communicate with younger audiences.

\section{Elaboration Likelihood Model (ELM)}

The ELM assumes people are motivated to hold correct attitudes, but they do not have the resources to process all persuasive arguments (Petty \& Cacioppo, 1986). Elaboration refers to how individuals think about or "mentally modify" (Perloff, 2014, p. 189) messages received. The ELM further explains that information can be processed in two ways: through central and peripheral processing routes (Petty \& Cacioppo, 1986). Through the central processing route, individuals thoughtfully consider messages and are more likely influenced by them. Through the peripheral route, individuals quickly examine messages and focus on cues to help them decide whether or not they will accept a message. They are also less likely to be influenced by these messages. Critical thinking and attitude changes can occur through thoughtful consideration or elaboration of

1. This document is AEC660, one of a series of the Agricultural Education and Communication Department, UF/IFAS Extension. Original publication date November 2018. Visit the EDIS website at https://edis.ifas.ufl.edu for the currently supported version of this publication.

2. Amanda D. Ali, graduate student, Department of Agricultural Education and Communication; Laura A. Sanagorski Warner, assistant professor, Department of Agricultural Education and Communication; Ashley N. McCleod, public relations specialist, UF/IFAS PIE Center; Shelli Rampold, research coordinator, UF/IFAS PIE Center; and Alexa J. Lamm, associate professor, University of Georgia Department of Agricultural Leadership, Education and Communication; UF/IFAS Extension, Gainesville, FL 32611.

The Institute of Food and Agricultural Sciences (IFAS) is an Equal Opportunity Institution authorized to provide research, educational information and other services only to individuals and institutions that function with non-discrimination with respect to race, creed, color, religion, age, disability, sex, sexual orientation, marital status, national origin, political opinions or affiliations. For more information on obtaining other UF/IFAS Extension publications, contact your county's UF/IFAS Extension office. 
messages when processing information through the central processing route (Petty, Cacioppo, \& Schumann, 1983). Elaboration requires motivation and an ability to process information (Petty \& Cacioppo, 1986). Individuals are more likely to carefully consider information when exposed to persuasive messages if they are motivated. When designing educational video messages about good fertilizer application, Extension professionals could consider using persuasive messages and identifying how different audiences react to those messages. Figure 1 provides an overview of the ELM.

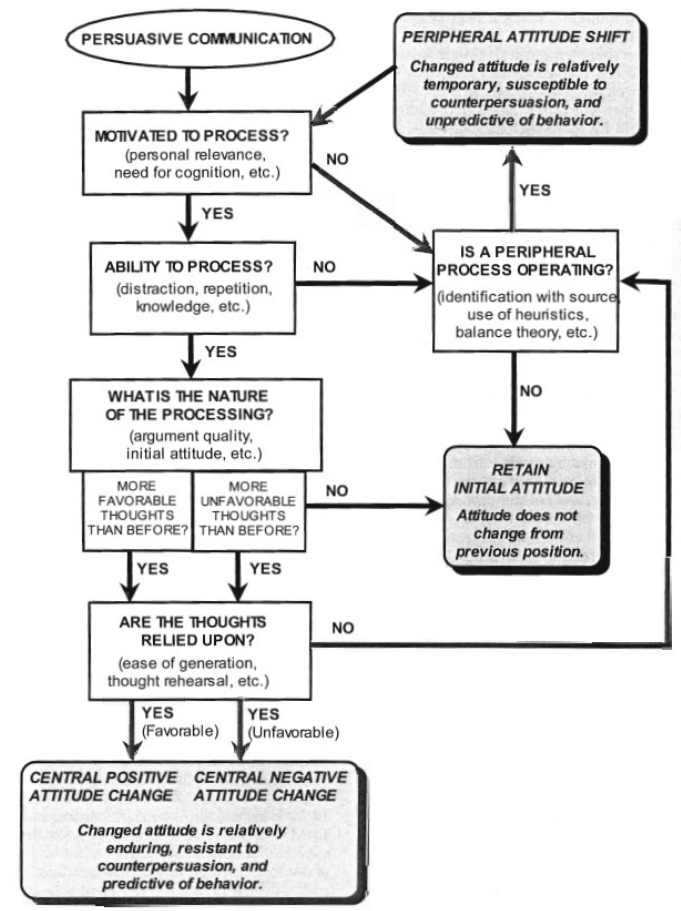

Figure 1. The Elaboration Likelihood Model.

Credits: Adapted from "The Elaboration Likelihood and Metacognitive Models of Attitudes" by R. E. Petty and P. Briñol, 2009, in J. W. Sherman, B. Gawronski, and Y. Trope (Eds.) in Dual-process theories of the social mind, p. 174

\section{How Residents Processed Video Messages about Fertilizer Best Practices}

A team of researchers from the Center for Landscape Conservation and Ecology (clce.ifas.ufl.edu) and the Center for Public Issues Education (www.piecenter.com) surveyed 2,000 Florida residents who were responsible for their home lawn care. The researchers used a third-party survey company, Qualtrics, to administer an online questionnaire. Respondents were asked to reflect on their experience watching a 30-second educational video on proper fertilizer application and indicate their level of agreement with 12 items pertaining to how they processed information during the video (see Table 1). The items measured how much cognitive effort and evaluative processing took place while individuals watched the videos (Carpenter \& Boster, 2013). Responses were collected using a seven-point Likert-type scale where 1 = Entirely Disagree, 2 = Mostly Disagree, 3 =Somewhat Disagree, $4=$ Neither Disagree nor Agree, $5=$ Somewhat Agree, $6=$ Mostly Agree, and $7=$ Entirely Agree . Respondents were also divided into two age groups: those aged 30 years or younger and those over 30 years old. This division was used because exploratory data analysis revealed the greatest practical differences emerged when using 30 as a cutoff point. Results showed participants in both age categories agreed with statements about their information processing behaviors for the fertilizer video messages. Table 1 shows there were associations between age groups for respondents:

- being deep in thought about messages

- searching their minds in response to the ideas

- extending a good deal of cognitive effort

- taking it easy

- resting their minds

- not really exerting their minds

- distracted by other thoughts not related to the message

- unconcerned with the ideas

Respondents 30 years or younger agreed to some degree they were deep in thought about the message (77.4\%), searching their minds in response to the ideas $(72.5 \%)$, extending a great deal of cognitive effort (73.0\%), and taking it easy (48.5\%). Respondents in this group disagreed to some degree they were resting their minds (40.3\%), not really exerting their minds $(66.0 \%)$, distracted by other thoughts not related to the message $(74.6 \%)$, and were unconcerned with the ideas (71.6\%).

Respondents 30 years or older agreed to some degree they were deep in thought about the message (66.3\%), searching their minds in response to the ideas (61.2\%), and extending a great deal of cognitive effort (62.2\%). Respondents in this group disagreed to some degree they were taking it easy (40.1\%), resting their minds (56.4\%), not really exerting their minds (68.3\%), distracted by other thoughts not related to the message $(81.2 \%)$, and were unconcerned with the ideas (83.9\%).

\section{Conclusion and Recommendations}


Overall, the information processing behavior of respondents was similar for both groups. The results suggest respondents processed video information through the central route, meaning both groups were likely to carefully analyze the fertilizer messages. This finding implies there is value in communicating about applying fertilizer properly to protect water quality with Extension audiences through videos. Extension professionals can consider integrating short videos into their programs which can have a positive influence on target audiences.

When watching a 30 -second educational video, respondents 30 years of age or younger were more likely to be deep in thought about the message, searching their minds in response to the ideas, and extending a good deal of cognitive effort than respondents over the age of 30 . At the same time, respondents 30 years or younger were also likely to be taking it easy and resting their minds than respondents older than 30 . While more research is needed to explore these findings, they suggest respondents under 30 needed to exert less cognitive effort to evaluate the messages (Carpenter \& Boster, 2013). It is possible this is because the younger group is either more comfortable receiving information through videos, or they are familiar with landscape practices to protect water quality, or some combination of these two possibilities. Video messages may not always target specific age groups when promoting fertilizer best practices. It is possible different message design strategies could be more effective for different age groups, but more research is needed to clarify what these approaches would look like. Overall, because both groups likely processed information centrally, fertilizer messages should include information appealing to careful thought and critical thinking.

Videos can be a useful tool in promoting adoption of fertilizer best practices in water quality Extension programs. Both groups considered the messages and were highly involved in examining "all the information presented" (Rucker \& Petty, 2006, p. 41). Because participants responded positively to video messages, Extension professionals can consider short videos in their water quality programs to promote good fertilizer practices. When audiences process information through the central route, their attitudes are likely more strongly in favor of the message. Attitudes formed depend on elements of the message itself, such as the argument presented or the relevancy of the issue. There is a greater likelihood attitudes toward the message persist over time when message elements or characteristics are strong. It is also likely for positive influences on other behaviors when strong positive attitudes persist. A behavior change is possible depending on how information is processed, either centrally or peripherally. Because both age groups were inclined to process fertilizer messages centrally, fertilizer video messages should:

- Emphasize the importance and relevance of good fertilizer practices-highlighting how good fertilizer practices help to promote environmental conservation and clean water bodies for future generations can help strengthen positive attitudes toward good fertilizer practices.

- Present positively framed arguments-appealing to the audience's ability to change negative fertilizer behaviors can influence long-term behavior change. Messages portraying how individuals could engage in good fertilizer practices may help create a sense of action that can persist over time. For example, messages can indicate how small acts such as reading fertilizer labels carefully help prevent fertilizer runoff into stormdrains. This in turn promotes clean water in local lakes which could stimulate a "can do" attitude towards engagement in good fertilizer practices.

Use less distractive elements in the message-message characteristics such as background music or excessive graphics can navigate attention away from the message itself. While it is important to include some visual aids, audiences with high levels of elaboration tend to respond positively to messages with compelling arguments. It means, therefore, the message should focus on encouraging good fertilizer practices as opposed to catchy background music. These design strategies will help to promote strong, persistent, and positive attitudes in the long-term as individuals critically think about the messages presented to them.

\section{Acknowledgements}

The authors thank the Center for Landscape Conservation and Ecology for supporting the work shared in this publication.

\section{References}

Carpenter, C. J., \& Boster, F. J. (2013). Modeling the effects of processing effort and ability in response to persuasive message arguments. Communication Quarterly, 61(4), 413-430. doi:10.1080/01463373.2013.799509

Lamm, A. J., Warner, L. A., Martin, E. T., White, S. A., \& Fisher, P. (2017). Enhancing extension programs by discussing water conservation technology adoption with growers. Journal of Agricultural Education, 58(1), 251-266. doi:10.5032/jae.2017.01251 
Moore, M. L., Meyers, C., Irlbeck, E., \& Burris, S. (2015).

U.S. agricultural commodity organizations' use of blogs as a communications tool. Journal of Applied Communications, 99(2), 61-75. doi:10.4148/1051-0834.1048

Perloff, R. M. (2014). The dynamics of persuasion. Communication and attitudes in the 21 century (5th ed.). Westford, MA: Taylor \& Francis

Petty R. E., \& Briñol, P. (2009). The elaboration likelihood and metacognitive models of attitudes. In J. W. Sherman, B. Gawronski, and Y. Trope (Eds.), Dual-process theories of the social mind (pp. 172-187). New York, NY: Guilford Press.

Petty, R. E., \& Cacioppo, J. T. (1986). Communication and persuasion: Central and peripheral routes to attitude change. New York, NY: Springer/Verlag.

Petty, R. E., Cacioppo, J. T., \& Schumann, D. (1983). Central and peripheral routes to advertising effectiveness: The moderating role of involvement. Journal of Consumer Research, 10(2), 135-146. doi:10.1086/208954

Rucker, D. D, \& Petty, R. E. (2006). Increasing effectiveness of communications to consumers: Recommendations based on elaboration likelihood and attitude certainity perspectives. Journal of Public Policy and Marketing, 25(1), 39-52. doi:10.1509/jppm.25.1.39

Shaddox, T. W., \& Unruh, J. B. (2017). Florida fertilizer usage statistics. ENH1277. Gainesville: University of Florida Institute of Food and Agricultural Sciences. http://edis.ifas. ufl.edu/ep541 
Table 1. Respondents' agreement with their informational processing behaviors.

\begin{tabular}{|c|c|c|c|c|}
\hline Items & a Disagree (\%) & $\begin{array}{l}\text { Neither agree nor } \\
\text { disagree (\%) }\end{array}$ & ${ }^{\mathrm{b}}$ Agree (\%) & $c^{2}$ \\
\hline \multicolumn{5}{|c|}{$\begin{array}{l}\text { Attempting to analyze the issues in the } \\
\text { message }\end{array}$} \\
\hline 30 years or younger & 4.9 & 12.0 & 83.1 & \multirow[t]{2}{*}{8.74} \\
\hline Over 30 years old & 6.6 & 20.0 & 73.3 & \\
\hline \multicolumn{5}{|c|}{ Doing your best to think about what was said } \\
\hline 30 years or younger & 8.7 & 11.4 & 79.9 & 6.11 \\
\hline Over 30 years old & 5.4 & 10.2 & 84.4 & \\
\hline \multicolumn{5}{|c|}{ Deep in thought about the message } \\
\hline 30 years or younger & 8.3 & 14.4 & 77.4 & $17.42^{* *}$ \\
\hline Over 30 years old & 9.5 & 24.3 & 66.3 & \\
\hline \multicolumn{5}{|c|}{$\begin{array}{l}\text { Reflecting on the implications of the } \\
\text { argument }\end{array}$} \\
\hline 30 years or younger & 6.5 & 20.2 & 73.2 & 2.01 \\
\hline Over 30 years old & 7.1 & 22.0 & 70.8 & \\
\hline \multicolumn{5}{|c|}{ Searching your mind in response to the ideas } \\
\hline 30 years or younger & 7.0 & 20.5 & 72.5 & $15.20^{* *}$ \\
\hline Over 30 years old & 10.1 & 28.6 & 61.2 & \\
\hline \multicolumn{5}{|c|}{ Extending a good deal of cognitive effort } \\
\hline 30 years or younger & 7.5 & 19.5 & 73.0 & $12.70^{*}$ \\
\hline Over 30 years old & 12.4 & 25.4 & 62.2 & \\
\hline \multicolumn{5}{|l|}{ Taking it easy } \\
\hline 30 years or younger & 25.2 & 26.4 & 48.5 & $101.51^{* * *}$ \\
\hline Over 30 years old & 40.1 & 38.9 & 21.0 & \\
\hline \multicolumn{5}{|l|}{ Resting your mind } \\
\hline 30 years or younger & 40.3 & 28.7 & 31.1 & $54.69^{* * *}$ \\
\hline Over 30 years old & 56.4 & 32.6 & 10.9 & \\
\hline \multicolumn{5}{|l|}{ Not really exerting your mind } \\
\hline 30 years or younger & 66.0 & 16.9 & 17.0 & $11.39^{*}$ \\
\hline Over 30 years old & 68.3 & 20.3 & 11.4 & \\
\hline \multicolumn{5}{|c|}{ Not very attentive to the ideas } \\
\hline 30 years or younger & 72.7 & 12.5 & 14.8 & 8.07 \\
\hline Over 30 years old & 80.7 & 9.8 & 9.5 & \\
\hline \multicolumn{5}{|c|}{$\begin{array}{l}\text { Distracted by other thoughts not related to } \\
\text { the message }\end{array}$} \\
\hline 30 years or younger & 74.6 & 11.0 & 14.5 & $14.95^{* *}$ \\
\hline Over 30 years old & 81.2 & 12.1 & 6.7 & \\
\hline \multicolumn{5}{|l|}{ Unconcerned with the ideas } \\
\hline 30 years or younger & 71.6 & 15.0 & 13.3 & $20.62^{* * *}$ \\
\hline Over 30 years old & 83.9 & 10.0 & 6.2 & \\
\hline
\end{tabular}

